\title{
Sensitivity of Phakopsora pachyrhizi Isolates to Fungicides and Reduction of Fungal Infection Based on Fungicide and Timing of Application
}

\author{
M. Twizeyimana, Dept. of Crop Sciences, University of Illinois, Urbana, IL 61801; and G. L. Hartman, United States Department of
} Agriculture-Agricultural Research Service, and Department of Crop Sciences, University of Illinois, Urbana, IL 61801

\begin{abstract}
Soybean rust (SBR), caused by Phakopsora pachyrhizi, is a damaging foliar fungal disease in many soybean-growing areas of the world. Strategies to manage SBR include the use of foliar fungicides. Fungicide types, the rate of product application, and the number and timing of applications are critical components for successful rust management. The objectives of this study were to determine i) the sensitivity of $P$. pachyrhizi isolates collected in the U.S. to a range of fungicides and ii) the reduction of fungal infection based on fungicide type and timing of applications on soybean. There were differences $(P<0.05)$ in effective

concentration $\left(\mathrm{EC}_{50}\right)$ values among the fungicides tested. Azoxystrobin had low $\mathrm{EC}_{50}$ values for both urediniospore germination and fungal sporulation on inoculated leaflets. There were differences $(P<0.05)$ in fungal sporulation for application times, fungicide treatments, and their interaction when the fungus was inoculated on plants. All application times and nearly all fungicide treatments reduced $(\alpha=0.05)$ fungal infection compared with the nonfungicide control. Information on fungicide sensitivity of $P$. pachyrhizi isolates and the preventive and curative effects of different fungicides are important in the management of SBR.
\end{abstract}

Soybean rust (SBR), caused by the obligate fungal pathogen Phakopsora pachyrhizi Syd., is one of the most damaging foliar fungal diseases of soybean (Glycine max [L.] Merr.) in many soybeangrowing areas throughout the world (Hartman et al. 2015). Yield losses of up to $80 \%$ caused by SBR have been reported in experimental trials in Asia (Hartman et al. 1991), 60\% in Brazil and Paraguay (Yorinori et al. 2005), and up to $27 \%$ and $60 \%$, respectively, in experimental plots and a commercial field in the United States (Mueller et al. 2009; Sikora 2013). P. pachyrhizi is known to overwinter on a perennial host (kudzu, Pueraria lobata) in the southern United States along the Gulf of Mexico (Park et al. 2008), which provides a source of urediniospores to initiate infections in the U.S. soybean crop each year as the pathogen spreads from the southern to northern growing regions (USDA 2016).

Strategies available to manage SBR include the use of fungicides (Levy 2005; Miles et al. 2007; Mueller et al. 2009; Sikora et al. 2014), planting resistant cultivars (Twizeyimana et al. 2008), and adopting cultural practices such as changing the time of planting (Twizeyimana et al. 2011). Information from the Soybean Rust-Pest Information Platform for Extension and Education (SBR-PIPE) has been vitally important in the education of growers, consultants, and the entire agriculture industry on the identification, management, movement, and risk of SBR during the growing season (Isard et al. 2015; Kelly et al. 2015; Sikora et al. 2014).

Fungicides, consisting of triazoles, strobilurins, and their mixtures, are considered the most effective way to manage SBR and are widely used in most commercial soybean fields in Brazil and the U.S. when rust occurs (Godoy 2012; Sikora et al. 2014). The triazole fungicides inhibit the C-14 demethylation step in fungal sterol biosynthesis and are thus commonly characterized as sterol biosynthesis inhibitors or

Corresponding author: G. L. Hartman; E-mail: ghartman@illinois.edu

Current address for M. Twizeyimana: AgBiome, Inc., Research Triangle Park, NC 27709

Trade and manufacturers' names are necessary to report factually on available data; however, the USDA neither guarantees nor warrants the standard of the product, and the use of the name by USDA implies no approval of the product to the exclusion of others that may also be suitable.

Accepted for publication 27 June 2016.

This article is in the public domain and not copyrightable. It may be freely reprinted with customary crediting of the source. The American Phytopathological Society, 2017. demethylation inhibitors (DMI). The strobilurin fungicides belong to the group of chemicals classified as quinone outside inhibitor (QoI) fungicides; this group blocks electron transport at the quinol-oxidizing site of the cytochrome $b$ complex (complex III) in the mitochondria, disrupting ATP production, and are especially effective against spore germlings (Bartlett et al. 2002). Some progress has been made in the deployment of resistant cultivars in Brazil, although single dominant genes controlling SBR resistance have been shown to be ineffective against at least some isolates of the fungus (Hartman et al. 2005; Twizeyimana and Hartman 2012; Twizeyimana et al. 2008).

The early research in evaluating fungicides to manage SBR conducted in Asia indicated that protective compounds such as mancozeb were effective in reducing disease severity and providing some yield protection (Miles et al. 2003). Disease control was greatly improved in India following the introduction of triazole fungicides such as difenoconazole, hexaconazole, propiconazole, and triadimefon, which performed better than mancozeb (Patil and Anahosur 1998). Additional triazoles as well as several strobilurin fungicides and mixtures were evaluated in South Africa and Zimbabwe (Levy 2005; Miles et al. 2003, 2007). The spread of SBR to Brazil and the U.S. prompted the registration and use of several triazole and strobilurin fungicides and their mixtures to manage the disease (Godoy 2012; Miles et al. 2007; Mueller et al. 2009; Sikora et al. 2014). Combinations of strobilurins with triazole fungicides tend to be more consistent, reducing the severity of SBR and resulting in less yield losses when compared with either class alone (Godoy 2012). Fungicides that provide better disease control were reported to be associated with higher yields (Scherm et al. 2009).

The type of fungicide and number and timing of applications are critical to manage SBR. Preventive fungicides may be effective in controlling SBR, but timing of applications in the absence of symptoms becomes crucial; unnecessary fungicide applications may result in increased production costs and cause unforeseen consequences due to activity on nontarget fungi (Jarvie 2009). When fungicides are used curatively, the number of applications required for disease control depends on the compounds used and the favorability of ensuing weather conditions for continued disease development (Mueller et al. 2009). In some areas, high levels of inoculum early in the season result in SBR epidemics starting well before flowering, forcing growers to apply fungicides at early vegetative growth stages and increasing the number of applications used if the epidemic continues. Such early disease onset and early need for fungicide applications are unlikely in most soybean growing areas of the U.S., where the disease occurs late in the season in 
the northern soybean production areas (Christiano and Scherm 2007; Hartman et al. 2007, Koenning et al. 2007; Li et al. 2008; Watson et al. 2008). However, in the southern U.S., growers will apply one to two fungicide applications per season usually initiated after bloom when the risk of SBR is relatively high (Sikora 2013; Sikora et al. 2014).

Fungal pathogens with isolates that are no longer controlled by fungicides are referred to as fungicide insensitive or fungicide resistant, and may occur in response to repeated use of the same fungicide or use of multiple fungicides with similar modes of action (Brent and Hollomon 2007). The development of resistance in fungal pathogens to fungicides is a concern for the worldwide agricultural industry (Ishii 2006). Isolate insensitivity to fungicides has been well documented for various plant pathogens (Jo et al. 2006; Miller and Gubler 2004; Tremblay et al. 2003). The effective concentration of the active ingredient that inhibits fungal growth or reproduction by $50 \%\left(\mathrm{EC}_{50}\right)$ has been used as an indicator of fungicide sensitivity (Brent 1988; Jo et al. 2006). According to the Fungicide Resistance Action Committee (FRAC), no $P$. pachyrhizi strains insensitive to either strobilurin or triazole fungicides have been reported in the U.S. In contrast, after 5 years of using fungicide to manage SBR in Brazil, some triazoles were reported to be ineffective in controlling the disease (Godoy 2012). The mechanism associated with this insensitivity was reported to be due to multiple independent point mutations, over-expression of the target gene cyp51, or upregulation of efflux-transporter (Schmitz et al. 2014). For QoI fungicides, the occurrence of the F129 L mutation in the cytochrome $b$ gene in $P$. pachyrhizi isolates from monouredinial isolates obtained from field samples may be responsible for decreased QoI sensitivity observed in soybean fields in Brazil (Klosowski et al. 2015).

The objectives of this study were to determine i) the sensitivity of $P$. pachyrhizi isolates collected in the U.S. to a range of fungicides and ii) the reduction of fungal sporulation on inoculated soybean leaves based on fungicide type and timing of application.

\section{Materials and Methods}

Isolates and plant material. Twenty-four isolates of $P$. pachyrhizi (Twizeyimana and Hartman 2012) originating from infected leaf samples of soybean and kudzu from eight states in the U.S. were used to test in vitro sensitivity to two fungicides. Additionally, one of the 24 isolates, FL07-1, was used alone in three experiments, including an in vitro test of sensitivity to 17 fungicides, a test of the effect of three fungicides and timing of application using detached leaflets, and a similar test of the fungicide and application timing conducted in the greenhouse on whole plants. To establish cultures of $P$. pachyrhizi, urediniospores (approximately 0.1 to $0.5 \mathrm{mg}$ ) harvested from two to six soybean or kudzu leaf samples at each location were used to inoculate the abaxial surface of leaf sections of Williams 82, a public cultivar susceptible to SBR. When sporulation occurred, 10 to 13 days after inoculation, single-spore isolates were obtained as previously described (Twizeyimana and Hartman 2010). Isolates were multiplied on detached leaflets of Williams 82 to produce adequate amounts of spores for the experiments. The details of maintenance and increase of spore numbers are described elsewhere (Twizeyimana and Hartman 2010).

The cultivar Williams 82 was used in all plant-related experiments and a susceptible commercial cultivar, Asgrow 2242, along with Williams 82 were used in the effect of fungicide and timing of application experiments. Detached leaflets for all in vitro experiments were obtained from plants grown inside a growth chamber (Percival Scientific, Inc.) maintained at 65 to $75 \%$ relative humidity with a cycle of $14 \mathrm{~h}$ of light $\left(500 \mu \mathrm{mol} \mathrm{m} \mathrm{s}^{-2} \mathrm{PAR}\right)$ at $25^{\circ} \mathrm{C}$ and $10 \mathrm{~h}$ of darkness at $23^{\circ} \mathrm{C}$.

Sensitivity of isolate FL07-1 to 17 fungicides. Seventeen fungicides belonging to different chemical families (Table 1) were amended into $1.5 \%$ water agar (WA) to determine their $\mathrm{EC}_{50}$ on urediniospore germination of isolate FL07-1. Fourteen commercially formulated fungicides were diluted in sterile water to prepare stock solutions of 1,000 $\mu \mathrm{g}$ a.i./ml (ppm a.i.). Benomyl and technicalgrade metconazole (a.i. 99.4\%) and prothioconazole (a.i. 99.9\%) were dissolved in $100 \%$ ethanol at $10 \mathrm{mg}$ a.i./ml to make stock solutions of each at $1,000 \mu \mathrm{g}$ a.i./ml. Fungicides were prepared by appropriate dilution of the stock solutions and added to WA, autoclaved and cooled to $55^{\circ} \mathrm{C}$, to obtain final concentrations of active ingredient at $0.005,0.05,0.1,0.5,1,2.5,5,10$, and $100 \mu \mathrm{g} / \mathrm{ml}$. Amended WA $(20 \mathrm{ml})$ was poured into 8.5 -cm-diameter petri dishes.

Four drops of urediniospore suspension $\left(25 \mu \mathrm{l}\right.$ each and at $1 \times 10^{5}$ spores/ml of sterile distilled water) were placed at different places on

Table 1. Fungicides used to determine the effective concentration of the active ingredient that inhibited both urediniospore germination on amended water agar and fungal sporulation in leaf tissue by $50 \%$ for Phakopsora pachyrhizi isolate FL07-1

\begin{tabular}{|c|c|c|c|c|c|}
\hline Active ingredient ${ }^{w}$ & Product name & Manufacturer & Chemical group & Group name ${ }^{x}$ & Code $^{y}$ \\
\hline Aluminum tris (80) & Aliette & Bayer CropScience & Ethyl-phosphonates & Phosphonates & 33 \\
\hline Azoxystrobin (22.9) & Quadris & Syngenta & \multirow{2}{*}{ Strobilurines (methoxyacrylates) } & \multirow{3}{*}{ QoI (quinone outside inhibitors) } & \multirow{3}{*}{11} \\
\hline Pyraclostrobin (20) & Cabrio & BASF & & & \\
\hline Trifloxystrobin (50) & Flint & Bayer CropScience & Strobilurines (oximino-acetates) & & \\
\hline Chlorothalonil (82.5) & Daconil & Syngenta & Chloronitriles & M5 & M \\
\hline Benomyl (50) & Benlate & Dupont & Benzimidazoles & MBC fungicides & 1 \\
\hline Boscalid (70) & Emerald & BASF & Carboxamides & SDHI & 7 \\
\hline Dimethomorph (50) & Stature SC & BASF & Cinnamic acid & CAA & 40 \\
\hline Fenhexamid (50) & Elevate & Arysta LifeScience & Hydroxyanilide & Hydroxyanilides & 17 \\
\hline Fludioxonil (50) & Medallion & Syngenta & Phenylpyrrole & Phenylpyrroles & 12 \\
\hline Mefenoxam (45.3) & Ridomil Gold & Syngenta & Acylalanines & Phenylamides & 4 \\
\hline Metconazole (99.4) & Technical grade & & & & \\
\hline Myclobutanil (19.7) & Eagle 20EW & \multicolumn{2}{|l|}{ Dow AgroSciences } & & \\
\hline Propiconazole (14.3) & Spectator & Lesco Inc. & \multirow[t]{3}{*}{ Triazoles } & \multirow{3}{*}{ DMI (de- methylation inhibitors) } & \multirow[t]{3}{*}{3} \\
\hline Prothioconazole (99.9) & Technical grade & \multirow{2}{*}{ Bayer CropScience } & & & \\
\hline Tebuconazole (38.7) & Folicur & & & & \\
\hline Metrafenone (30) & Vivando & BASF & Benzophenone & U8 & \multirow{2}{*}{$\begin{array}{l}U \\
1 \& 3\end{array}$} \\
\hline $\begin{array}{l}\text { Azoxystrobin }(7)+ \\
\text { propiconazole }(11.7)^{z}\end{array}$ & Quilt & Syngenta & Strobilurine + triazole & QoI + DMI & \\
\hline \multicolumn{6}{|c|}{$\begin{array}{l}\text { w Numbers in parentheses are percentages of active ingredient, aluminum tris = fosetyl-Al (aluminum tris O-ethyl phosphonate). } \\
\times \text { MBC-fungicides (methyl benzimidazole carbamates), SDHI (succinate dehydrogenase inhibitors), CAA-fungicides (carboxylic acid amides), M5: multisite } \\
\text { contact activity, U8: unknown mode of action (proposed - actin disruption). }\end{array}$} \\
\hline \multicolumn{6}{|c|}{$\begin{array}{l}\text { y FRAC Code List 2016: Fungicides sorted by mode of action (including FRAC Code numbering) (http://www.frac.info/docs/default-source/publications/ } \\
\text { frac-code-list/frac-code-list-2016.pdf?sfvrsn=2). }\end{array}$} \\
\hline \multicolumn{6}{|c|}{$\begin{array}{l}{ }^{z} \text { Quilt (azoxystrobin + propiconazole) was not used to test the effective concentration on urediniospore germination, but was used in other experiments dealing } \\
\text { with plant inoculations to evaluate fungal sporulation. }\end{array}$} \\
\hline
\end{tabular}


amended solidified agar. Petri dishes with nonamended WA were used as the control. After incubating at $24^{\circ} \mathrm{C}$ for $6 \mathrm{~h}$ in the dark, 50 spores on each plate were observed under a dissecting microscope at $20 \times$ magnification to record germination. A urediniospore was rated as germinated if a normally developing germ tube was greater than thrice the length of the urediniospore (about $90 \mu \mathrm{m}$ ). The experiment was conducted twice, with triplicate plates used for each concentration and the control.

Isolate FL07-1, the fungicides and concentrations were also evaluated in a detached-leaf assay conducted as previously described (Twizeyimana and Hartman 2010). Excised leaflets from Williams 82 plants grown in a growth chamber were rinsed in three changes of sterile distilled water, cut into sections (approximately 2 by $4 \mathrm{~cm}$ ), and placed adaxial side down on 150-mm-diameter filter papers (Whatman International Ltd., Kent, England) in plastic petri dishes $140 \mathrm{~mm}$ in diameter by $20 \mathrm{~mm}$ deep with sterile filter papers (two per dish) saturated with sterile distilled water (approximately $5 \mathrm{ml} / \mathrm{dish}$ ). Abaxial leaf surface was sprayed with $150 \mu$ l of treatment solution or a control. Fungicide concentrations used were identical to those in the amended WA experiment, and the control was sprayed with water. One day after application of the fungicide treatment, leaf sections were inoculated with $150 \mu$ l of a spore suspension $\left(1 \times 10^{5}\right.$ spores $/ \mathrm{ml}$ of sterile distilled water). An atomizer attached to an air compressor was used to apply both the fungicide treatments and the urediniospores. Petri dishes with leaf sections were placed inside zip bags (Webster Industries, Peabody, MA) and incubated $12 \mathrm{~h}$ in the dark, followed by a cycle of $14 \mathrm{~h}$ of light $\left(380 \mu \mathrm{mol} \mathrm{m} \mathrm{m}^{-2} \mathrm{~s}^{-1}\right)$ and $10 \mathrm{~h}$ of darkness inside a tissue culture chamber (Percival Scientific, Inc.) maintained at $23^{\circ} \mathrm{C}$. The leaflets were rated 14 days after inoculation by counting the number of sporulating uredinia in an arbitrarily selected $1-\mathrm{cm}$ area of leaf tissue. The experiment was conducted twice, with triplicate plates used for each concentration and the control.

Sensitivity of $\mathbf{2 4}$ isolates to two fungicides. Urediniospores of 24 isolates were germinated on $1.5 \%$ WA either not amended (control) or amended with different concentrations of two commercial fungicide formulations, azoxystrobin and tebuconazole, at concentrations of $0.005,0.15,1,2.5$, and $5 \mu \mathrm{g}$ a.i./ml and at $0.1,1,2,4,5$, and $10 \mu \mathrm{g}$ a.i./ml, respectively. The incubation, spore germination, and scoring were done in an identical manner to the previous experiment testing sensitivity of isolate FL07-1 to 17 fungicides. The experiment was a completely randomized design with three replications and was repeated once.

Effect of fungicide and timing of application on the number of sporulating uredinia of isolate FL07-1 using detached leaves. Three commercial fungicide formulations, azoxystrobin, tebuconazole, and azoxystrobin + propiconazole (Table 1), isolate FL-07, and detached leaflets of Williams 82 and Asgrow 2242 obtained from plants grown in a growth chamber as previously described were used in this experiment.

Azoxystrobin at $0.01,0.1$, and $0.5 \mu \mathrm{g}$ a.i./ml, tebuconazole at 0.5 , 1.5 , and $3 \mu \mathrm{g}$ a.i. $/ \mathrm{ml}$, and azoxystrobin + propiconazole at $0.01,0.1$, and $0.5 \mu \mathrm{g}$ a.i. $/ \mathrm{ml}$ and $0.02,0.17$ and $0.84 \mu \mathrm{g}$ a.i. $/ \mathrm{ml}$, respectively, were applied on the abaxial surface of leaf pieces using an atomizer attached to an air compressor 2, 4, 6, and 8 days before inoculation or 0 (actually $3 \mathrm{~h}$ after inoculation), 2, 4, 6, and 8 days after inoculation. Leaf pieces without fungicide treatment served as controls. A spore suspension of isolate FL07-1 ( $1 \times 10^{5}$ spores $/ \mathrm{ml}$ of sterile distilled water $)$ was sprayed before or after fungicide application on the abaxial surface of leaf pieces ( $150 \mu \mathrm{l}$ each piece) using an atomizer attached to an air compressor. Leaf pieces were placed adaxial side down on two watersaturated sterile 150 -mm-diameter filter papers in plastic petri dishes that were incubated inside a tissue chamber as previously described.

The experimental design was a split plot-randomized complete block with three replications. The main plot was the timing of the fungicide applications (seven treatments). The subplot was the fungicide type/concentration (nine treatments) and the control (inoculated without fungicide). Leaflets were rated 14 days after inoculation by counting the number of sporulating uredinia in an arbitrarily selected $1-\mathrm{cm}^{2}$ area of leaf tissue. The experiment was repeated once with each cultivar.
Effect of fungicide and timing of application on the number of sporulating uredinia of isolate FL07-1 on plants. The experiment was conducted in a biosafety level 2 greenhouse set for $22 \pm 2{ }^{\circ} \mathrm{C}$ under a 16-h photoperiod with supplemental illumination provided by 1,000-W Metalarc high-intensity lamps (Sylvania, Danvers, MA). The fungicides, their concentrations, the application timing of the fungicides, the control, and the experimental design were identical to those in experiment on the effect of fungicide and timing on isolate FL07-1 except that only one cultivar was used. Seeds of Williams 82 were sown in soil-less mix (Sunshine Mix, LC1; Sun Gro Horticulture Inc.) in 18-cell plastic inserts inside a flat with drainage holes $(52 \times 26 \times 6 \mathrm{~cm}$; Hummert International $)$, and fertilized at planting with slow-release pellets (Osmocote $19-6-12 ; 1$ to 2 pellets per $\mathrm{cm}^{2}$ ). Plants were thinned to one plant per cell after emergence. Plants at growth stage V2 (Fehr et al. 1971) were inoculated with a spore suspension of isolate FL07-1 $\left(1 \times 10^{5}\right.$ spores $/ \mathrm{ml}$ of sterile distilled water) until runoff using a hand sprayer. The plants were rated 14 days after inoculation by counting the number of sporulating uredinia in an arbitrarily selected $1-\mathrm{cm}^{2}$ leaf tissue of from an inoculated trifoliate. The experiment was repeated.

Data analyses. To determine the $\mathrm{EC}_{50}$ in the fungicide sensitivity experiments, four to five parameter logistic (sigmoidal) functions were tested and selection was based on the best fit selected (Hincapie et al. 2014); functions were plotted using SigmaPlot (version 11.0; Systat Software, Inc., San Jose, CA).

Data from repeated experiments were tested for homogeneity of error variance by analysis of variance (ANOVA) in PROC GLM of SAS (version 9.2; SAS Institute Inc., Cary, NC). As no heterogeneity was detected, runs were pooled together and tested by analysis of variance (ANOVA) using PROC GLM of SAS.

Means $\mathrm{EC}_{50}$ values were compared using Fisher's protected least significant difference (LSD) mean separation test at $\alpha=0.05$. Pearson's correlation (PROC CORR) was used to establish the relationship between $\mathrm{EC}_{50}$ values of azoxystrobin and tebuconazole in the fungicide sensitivity test of different isolates, and numbers of sporulating uredinia per leaf area of Asgrow 2242 and Williams 82 in the effect of fungicide and timing of application experiments on detached leaves. Also, the relationship between numbers of sporulating uredinia per leaf area recorded only on Williams 82 in the effect of fungicide and timing of application experiments on detached leaves and greenhouse was examined. A paired sample $t$-test was conducted to examine whether there were differences between $\mathrm{EC}_{50}$ values of azoxystrobin and tebuconazole, and $\mathrm{EC}_{50}$ values for urediniospore germination and fungal colonization, in the fungicide sensitivity test of 24 isolates.

\section{Results}

Sensitivity of isolate FL07-1 to 17 fungicides. Based on ANOVA, differences $(P<0.05)$ in $\mathrm{EC}_{50}$ values were observed among fungicides tested. For urediniospore germination, the strobilurin fungicides (azoxystrobin and pyraclostrobin) and aluminum tris had $\mathrm{EC}_{50}$ values lower $(\alpha=0.05)$ than fenhexamid and mycobutanil, and all fungicides had $\mathrm{EC}_{50}$ values lower $(\alpha=0.05)$ than mycobutanil (Table 2$)$. Urediniospores did not germinate at concentrations of active ingredient greater than $2.5 \mu \mathrm{g} / \mathrm{ml}$ and $20 \mu \mathrm{g} / \mathrm{ml}$ for the strobilurins and chlorothalonil, respectively, while urediniospore germination ranged from 20 to $50 \%$ for the triazoles at a concentration of $100 \mu \mathrm{g} / \mathrm{ml}$ of active ingredient. For uredinia sporulation on detached leaf pieces, all fungicides had similar $\mathrm{EC}_{50}$ values except for aluminum tris, which had an $\mathrm{EC}_{50}$ value greater $(\alpha=0.05)$ than that of other fungicides (Table 2). Uredinia sporulation did not occur on leaf pieces treated with strobilurins and triazoles at concentrations of active ingredient greater than $2.5 \mu \mathrm{g} / \mathrm{ml}$, and with chlorothalonil concentrations of active ingredient at $100 \mu \mathrm{g} / \mathrm{ml}$. For all other fungicides, there was uredinia sporulation at $100 \mu \mathrm{g} / \mathrm{ml}$ active ingredient. Pearson's correlation showed no relationship $(P>0.05)$ between the $\mathrm{EC}_{50}$ values for urediniospore germination and for uredinia sporulation.

Sensitivity of 24 isolates to two fungicides. Based on ANOVA, differences $(P<0.05)$ in $\mathrm{EC}_{50}$ values were detected among $P$. pachyrhizi isolates for each fungicide. A two-tailed $t$-test indicated differences 
$(P=0.0001)$ between mean $\mathrm{EC}_{50}$ values obtained within each fungicide. $\mathrm{EC}_{50}$ values were lower on isolates treated with azoxystrobin than on isolates treated with tebuconazole, ranging from 0.04 to 0.27 and 1.54 to 3.71 , respectively (Table 3 ). For azoxystrobin, $\mathrm{EC}_{50}$ values for 18 of the 24 isolates did not differ $(\alpha=0.05)$ from the lowest $\mathrm{EC}_{50}$ value of 0.04 for isolate FL09-5; isolate AR08-21 had the highest $\mathrm{EC}_{50}$ value, which did not differ $(\alpha=0.05)$ from four other isolates (three from Florida and one from Alabama) (Table 3). For tebuconazole,

Table 2. The effective concentration $\left(\mathrm{EC}_{50}\right)$ of the active ingredient of 17 fungicides that inhibits spore germination in water agar and uredinia sporulation on detached leaves by $50 \%$ for Phakopsora pachyrhizi isolate FL07-1

\begin{tabular}{lcc}
\hline & \multicolumn{2}{c}{$\mathbf{E C}_{\mathbf{5 0}}$ values (mg/liter) } \\
\cline { 2 - 3 } Fungicide & Urediniospore germination & Uredinia sporulation $^{\mathbf{z}}$ \\
\hline Azoxystrobin & $0.23 \mathrm{a}$ & $0.21 \mathrm{a}$ \\
Aluminum tris & $0.25 \mathrm{a}$ & $80.36 \mathrm{~b}$ \\
Pyraclostrobin & $0.37 \mathrm{a}$ & $0.99 \mathrm{a}$ \\
Trifloxystrobin & $0.67 \mathrm{ab}$ & $1.01 \mathrm{a}$ \\
Chlorothalonil & $1.03 \mathrm{ab}$ & $1.62 \mathrm{a}$ \\
Metconazole & $2.19 \mathrm{ab}$ & $0.25 \mathrm{a}$ \\
Prothioconazole & $2.25 \mathrm{ab}$ & $0.22 \mathrm{a}$ \\
Benomyl & $2.55 \mathrm{ab}$ & $0.38 \mathrm{a}$ \\
Tebuconazole & $3.62 \mathrm{ab}$ & $0.23 \mathrm{a}$ \\
Mefenoxam & $3.97 \mathrm{ab}$ & $3.59 \mathrm{a}$ \\
Metrafenone & $4.30 \mathrm{ab}$ & $7.08 \mathrm{a}$ \\
Propiconazole & $4.36 \mathrm{ab}$ & $0.28 \mathrm{a}$ \\
Boscalid & $6.58 \mathrm{ab}$ & $0.18 \mathrm{a}$ \\
Dimethomorph & $6.88 \mathrm{ab}$ & $2.40 \mathrm{a}$ \\
Fludioxonil & $8.57 \mathrm{ab}$ & $2.41 \mathrm{a}$ \\
Fenhexamid & $11.17 \mathrm{~b}$ & $0.66 \mathrm{a}$ \\
Myclobutanil & $36.36 \mathrm{c}$ & $0.43 \mathrm{a}$ \\
\hline
\end{tabular}

${ }^{\mathrm{z}}$ Values followed by similar letters within each column are not significantly different by Fisher's least significant difference test at $\alpha=0.05$. the lowest $\mathrm{EC}_{50}$ value of 1.54 for AR08-9 did not differ from that of nine other isolates; the highest $\mathrm{EC}_{50}$ value of 3.71 for LA09-1 did not differ from that of six other isolates (Table 3). Pearson's correlation between mean $\mathrm{EC}_{50}$ values of both fungicides was positive ( $r=0.40, P<$ $0.0001)$. There was no difference $(P>0.05)$ between $\mathrm{EC}_{50}$ values obtained from isolates originated from infected leaf samples of soybean and kudzu for both azoxystrobin and tebuconazole (Table 3).

Effect of fungicide and timing of application on the number of sporulating uredinia of FL07-1 using detached leaves. There were differences $(P<0.05)$ in sporulating uredinia per $\mathrm{cm}^{2}$ leaf tissue for application times, fungicide treatments, and their interaction. There were 26.0 and 19.6 sporulating uredinia per $\mathrm{cm}^{2}$ on leaflets that had no fungicide application for Williams 82 and Asgrow 2242, respectively, averaged over all application times (Fig. 1). All application times and fungicide treatments reduced $(\alpha=0.05)$ the occurrence of sporulating uredinia per $\mathrm{cm}^{2}$ compared with the nonfungicide treatment except for: azoxystrobin $(0.01 \mu \mathrm{g}$ a.i. $/ \mathrm{ml})+$ propiconazole $(0.02 \mu \mathrm{g}$ a.i./ml) applied 8 days after inoculation for both cultivars; azoxystrobin $(0.01 \mu \mathrm{g}$ a.i. $/ \mathrm{ml})$ applied 8 days after inoculation for both cultivars; and azoxystrobin $(0.01 \mu \mathrm{g}$ a.i. $/ \mathrm{ml})+$ propiconazole $(0.02 \mu \mathrm{g}$ a.i. $/ \mathrm{ml})$ applied 6 days after inoculation for Asgrow 2242. The number of sporulating uredinia per $\mathrm{cm}^{2}$ leaf tissue did not differ $(\alpha=0.05)$ from zero sporulation for the following treatments: i) 8 days before inoculation for azoxystrobin at $0.5 \mu \mathrm{g}$ a.i. $/ \mathrm{ml}+$ propiconazole at $0.84 \mu \mathrm{g}$ a.i. $/ \mathrm{ml}$ and tebuconazole at $3 \mu \mathrm{g}$ a.i./ml on Asgrow 2242; ii) 6 days before inoculation for six of the nine fungicide treatments for both cultivars; iii) at 4,2 , and at 0 days before inoculation for all fungicide treatments; iv) at 2 and 4 days after inoculation for all fungicide treatments except azoxystrobin at $0.01 \mu \mathrm{g}$ a.i. $/ \mathrm{ml}+$ propiconazole at $0.02 \mu \mathrm{g}$ a.i. $/ \mathrm{ml}$ and azoxystrobin at $0.01 \mu \mathrm{g}$ a.i./ml for both cultivars; $\mathrm{v}$ ) at 6 days after inoculation for five of the nine fungicide treatments for both cultivars; and vi) at 8 days after inoculation for azoxystrobin at $0.5 \mu \mathrm{g}$ a.i. $/ \mathrm{ml}+$ propiconazole at $0.84 \mu \mathrm{g}$ a.i. $/ \mathrm{ml}$, tebuconazole at $3 \mu \mathrm{g}$ a.i. $/ \mathrm{ml}$, and azoxystrobin at $0.5 \mu \mathrm{g}$ a.i./ml for Asgrow 2242, but not for Williams 82. Pearson's correlation coefficient indicated a positive correlation

Table 3. The effective concentration of the active ingredient of two fungicides (an azoxystrobin and a tebuconazole) that inhibits spore germination by $50 \%$ for different Phakopsora pachyrhizi isolates

\begin{tabular}{|c|c|c|c|c|c|c|}
\hline \multicolumn{7}{|c|}{$\mathrm{EC}_{50}$ values $(\mathrm{mg} / \mathrm{liter})^{\mathbf{y}}$} \\
\hline Isolate $^{x}$ & Host & County & State & Year & Azoxystrobin $^{z}$ & Tebuconazole $^{z}$ \\
\hline FL09-5 & Kudzu & Jefferson & Florida & 2009 & $0.04 \mathrm{a}$ & $1.78 \mathrm{ab}$ \\
\hline MS06-1 & Kudzu & Jefferson & Mississippi & 2006 & $0.04 \mathrm{a}$ & $1.58 \mathrm{a}$ \\
\hline FL09-3 & Kudzu & Taylor & Florida & 2009 & $0.05 \mathrm{a}$ & $2.62 \mathrm{~b}-\mathrm{h}$ \\
\hline FL09-1 & Kudzu & Taylor & Florida & 2009 & $0.06 \mathrm{ab}$ & $2.28 \mathrm{a}-\mathrm{f}$ \\
\hline OK07-1 & Soybean & Tulsa & Oklahoma & 2007 & $0.06 \mathrm{a}-\mathrm{c}$ & $3.69 \mathrm{j}$ \\
\hline AR08-5 & Soybean & Pulaski & Arkansas & 2008 & $0.08 \mathrm{a}-\mathrm{d}$ & $2.97 \mathrm{f}-\mathrm{j}$ \\
\hline MS07-4 & Soybean & Washington & Mississippi & 2007 & $0.08 \mathrm{a}-\mathrm{d}$ & $2.59 \mathrm{~b}-\mathrm{g}$ \\
\hline AR08-7 & Soybean & Clark & Arkansas & 2008 & $0.08 \mathrm{a}-\mathrm{d}$ & $2.30 \mathrm{a}-\mathrm{f}$ \\
\hline TX07-1 & Soybean & Hidalgo & Texas & 2007 & $0.08 \mathrm{a}-\mathrm{d}$ & $3.20 \mathrm{~g}-\mathrm{j}$ \\
\hline AR08-6 & Kudzu & Saline & Arkansas & 2008 & 0.09 a-e & $2.02 \mathrm{a}-\mathrm{d}$ \\
\hline AR08-15 & Soybean & Craighead & Arkansas & 2008 & 0.10 a-e & $3.49 \mathrm{i}-\mathrm{j}$ \\
\hline AR08-18 & Soybean & Randolph & Arkansas & 2008 & 0.10 a-e & $3.52 \mathrm{i}-\mathrm{i}$ \\
\hline AR08-9 & Soybean & Lonoke & Arkansas & 2008 & $0.11 \mathrm{a}-\mathrm{f}$ & $1.54 \mathrm{a}$ \\
\hline LA08-2 & Soybean & E Baton Rouge & Louisiana & 2008 & $0.11 \mathrm{a}-\mathrm{f}$ & $1.87 \mathrm{a}-\mathrm{c}$ \\
\hline AR08-20 & Soybean & Mississippi & Arkansas & 2008 & $0.12 \mathrm{a}-\mathrm{f}$ & $2.10 \mathrm{a}-\mathrm{e}$ \\
\hline AR08-3 & Soybean & Crawford & Arkansas & 2008 & $0.12 \mathrm{a}-\mathrm{f}$ & $2.27 \mathrm{a}-\mathrm{f}$ \\
\hline LA09-1 & Soybean & Bossier & Louisiana & 2009 & $0.12 \mathrm{a}-\mathrm{f}$ & $3.71 \mathrm{j}$ \\
\hline IL09-3 & Soybean & Saline & Illinois & 2009 & $0.14 \mathrm{a}-\mathrm{f}$ & $2.89 \mathrm{e}-\mathrm{j}$ \\
\hline TX09-1 & Kudzu & Livingston & Texas & 2009 & $0.16 \mathrm{~b}-\mathrm{f}$ & $2.80 \mathrm{~d}-\mathrm{i}$ \\
\hline AL08-2 & Kudzu & Mobile & Alabama & 2008 & $0.17 \mathrm{c}-\mathrm{g}$ & $2.67 \mathrm{c}-\mathrm{i}$ \\
\hline FL07-13 & Kudzu & Marion & Florida & 2007 & $0.18 \mathrm{~d}-\mathrm{g}$ & $2.71 \mathrm{c}-\mathrm{i}$ \\
\hline FL07-3 & Kudzu & Hernando & Florida & 2007 & $0.20 \mathrm{e}-\mathrm{g}$ & $2.77 \mathrm{~d}-\mathrm{i}$ \\
\hline FL07-1 & Soybean & Gadsden & Florida & 2007 & $0.21 \mathrm{f}-\mathrm{g}$ & $2.21 \mathrm{a}-\mathrm{f}$ \\
\hline AR08-21 & Soybean & Drew & Arkansas & 2008 & $0.27 \mathrm{~g}$ & $3.44 \mathrm{~h}-\mathrm{j}$ \\
\hline
\end{tabular}

${ }^{\mathrm{x}}$ Isolate name with three parts: $\left.\mathrm{i}\right)$ state of origin $(\mathrm{AL}=$ Alabama, $\mathrm{AR}=$ Arkansas, $\mathrm{FL}=$ Florida, $\mathrm{IL}=\mathrm{Illinois}, \mathrm{LA}=\mathrm{Louisiana}, \mathrm{MS}=\mathrm{Mississippi}, \mathrm{OK}=\mathrm{Oklahoma}$, and TX = Texas); ii) year of collection (2006 [06] to 2009 [09]); and iii) isolate number within location (Twizeyimana and Hartman 2012).

y Values followed by similar letters within each column are not significantly different by Fisher's least significant difference test at $\alpha=0.05$.

z The azoxystrobin and tebuconazole products used were commercial fungicide formulations Quadris and Folicur, respectively. 
( $r=0.85, P<0.0001$ ) between means of sporulating uredinia per $\mathrm{cm}^{2}$ of Asgrow 2242 and Williams 82 in these experiments.

Effect of fungicide and timing of application on the number of sporulating uredinia of FL07-1 on plants. There were differences $(P<0.05)$ in sporulating uredinia per $\mathrm{cm}^{2}$ leaf tissue for application times, fungicide treatments, and their interaction. There were 25.9 sporulating uredinia per $\mathrm{cm}^{2}$ on leaflets that had no fungicide applied (Fig. 2). All fungicide and application treatments reduced $(\alpha=0.05)$ sporulating uredinia per $\mathrm{cm}^{2}$ except for azoxystrobin at $0.1 \mu \mathrm{g}$ a.i. $/ \mathrm{ml}$ applied 8 days after inoculation. The number of sporulating uredinia per $\mathrm{cm}^{2}$ leaf tissue did not differ $(\alpha=0.05)$ from zero for the following treatments: i) at 8 days before inoculation for azoxystrobin at 0.5 $\mu \mathrm{g}$ a.i. $/ \mathrm{ml}+$ propiconazole at $0.84 \mu \mathrm{g}$ a.i. $/ \mathrm{ml}$ and for tebuconazole at $3 \mu \mathrm{g}$ a.i./ml, ii) at 4 days before inoculation for all fungicide treatments except azoxystrobin at $0.1 \mu \mathrm{g}$ a.i./ml, iii) at 2 and $3 \mathrm{~h}$ before inoculation for all fungicide treatments, iv) at 4 days after inoculation for all fungicide treatments except azoxystrobin at $0.1 \mu \mathrm{g}$ a.i. $/ \mathrm{ml}$, and v) at 8 days after inoculation, none of the fungicide treatments reduced the number of sporulating uredinia per $\mathrm{cm}^{2}$ leaf tissue equal to zero.
A significant positive correlation $(r=0.90, P<0.0001)$ was found between mean sporulating uredinia per $\mathrm{cm}^{2}$ recorded on Williams 82 from this experiment and from the experiment using using detached leaflets.

\section{Discussion}

Fungicides are a critical component in the management of SBR. Isolate sensitivity to fungicides, their overall efficacy, and the timing of application are main factors that may determine the success or failure of controlling the disease. Several studies have been conducted to determine the effect of fungicide and timing of application on control of SBR in the field (Levy 2005; Miles et al. 2007; Mueller et al. 2009; Patil and Anahosur 1998; Sikora et al. 2014), but there have been very few reports (Godoy 2012; Schmitz et al. 2014) on P. pachyrhizi isolate sensitivity to fungicides.

Depending on their modes of action, fungicides have the ability to inhibit one or more processes, including spore germination, mitochondrial respiration, germ tube elongation, and mycelial growth, and they may also have an indirect mode of action, such as enhancing
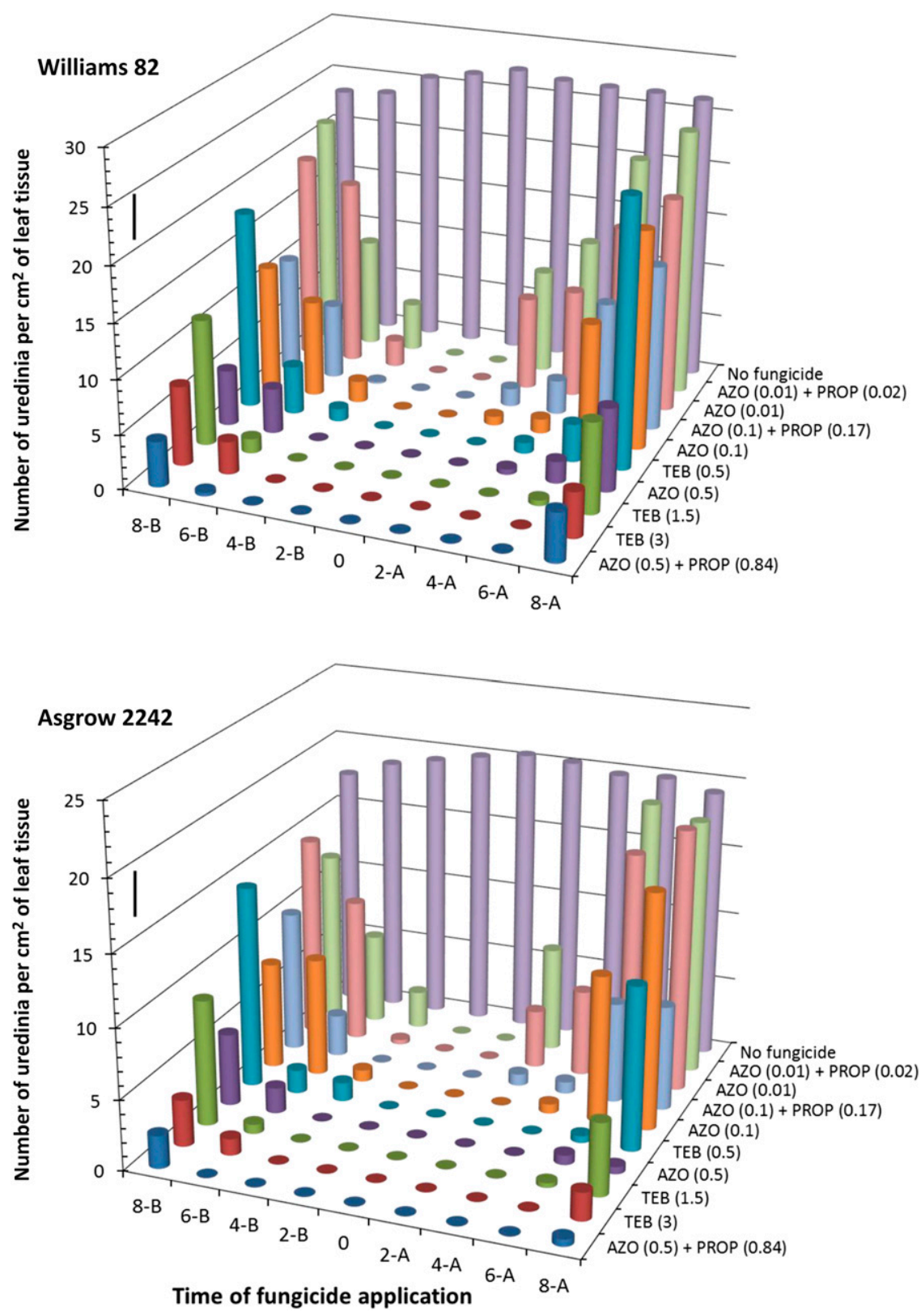

Fig. 1. Number of uredinia on detached leaves for soybean cultivars Williams 82 and Asgrow 2242 after applying or not applying fungicides 8 days before (8-B) to 8 days after (8-A) Phakopsora pachyrhizi inoculation. Fungicides are azoxystrobin (AZO), tebuconazole (TEB), and propiconazole (PROP) with rates in $\mu \mathrm{g}$ a.i./ml (ppm) after each fungicide. The vertical bar represents $L S D$ value at $\alpha=0.05$ for all treatments. 
host-defense mechanisms (Leroux 1996). Most fungicides included in our fungicide sensitivity study were effective at reducing urediniospore germination on amended WA and reducing uredinia sporulation on detached leaflets compared with the control, although two fungicides (fenhexamid and myclobutanil) had higher $\mathrm{EC}_{50}$ values for urediniospore germination than for uredinia sporulation; and aluminum tris had low $\mathrm{EC}_{50}$ values in urediniospore germination and high in uredinia sporulation. Fungicide sensitivity tests have to be simple, reliable, repeatable, and able to reflect sensitivity responses in the field (Russell 2005).

FRAC recommends using urediniospore germination when testing P. pachyrhizi sensitivity to strobilurins. This is in agreement with our results, as all strobilurin fungicides had similar $\mathrm{EC}_{50}$ values in urediniospore germination and uredinia sporulation. For triazoles, one fungicide in this group, myclobutanil, had a higher $\mathrm{EC}_{50}$ value for urediniospore germination than in uredinia sporulation, indicating that the fungicide sensitivity test on leaves would be suitable for fungicides in this group. This is again in accordance with FRAC recommendations. However, urediniospore germination testing may also be suitable for few fungicides in this group, e.g., metconazole, prothioconazole, and tebuconazole, that had similar $\mathrm{EC}_{50}$ values in urediniospore germination and uredinia sporulation in our study. Triazoles are sterol biosynthesis inhibitors that inhibit the C-14 demethylation step in fungal sterol biosynthesis. Previous studies have demonstrated that for some fungi, sterol biosynthesis starts after 6 to $8 \mathrm{~h}$ of germination time, almost at the end of the germ tube phase, while others are able to synthesize new sterols using exogenously supplied substrates very early after the beginning of germination before germ tubes have emerged (Pontzen and Scheinpflug 1989). In another study, P. pachyrhizi isolate sensitivity to two triazoles fungicides (metconazole and tebuconazole) produced low $\mathrm{EC}_{50}$ values for germ tube elongation inhibition (3.36 and $0.05 \mu \mathrm{g} / \mathrm{ml}$, respectively), but not for four other triazoles (cyproconazole, flutriafol, myclobutanil, and tetraconazole), which had high $\mathrm{EC}_{50}$ values ranging from 11.98 to $26.46 \mu \mathrm{g} / \mathrm{ml}$ (Blum and Reis 2013).

Fenhexamid, which had a higher $\mathrm{EC}_{50}$ value for urediniospore germination than for uredinia sporulation in our study, has been described as a sterol biosynthesis inhibitor fungicide (Debieu et al. 2001) like triazoles. Aluminum tris had a low $\mathrm{EC}_{50}$ value for urediniospore germination and high for uredinia sporulation in our study. In the previous studies, aluminum tris was reported to inhibit spore germination and germ-tube growth of Puccinia arachidis in vitro; percent inhibition of spore germination increased with increase in aluminum tris concentrations and there was nearly $50 \%$ inhibition of germ-tube

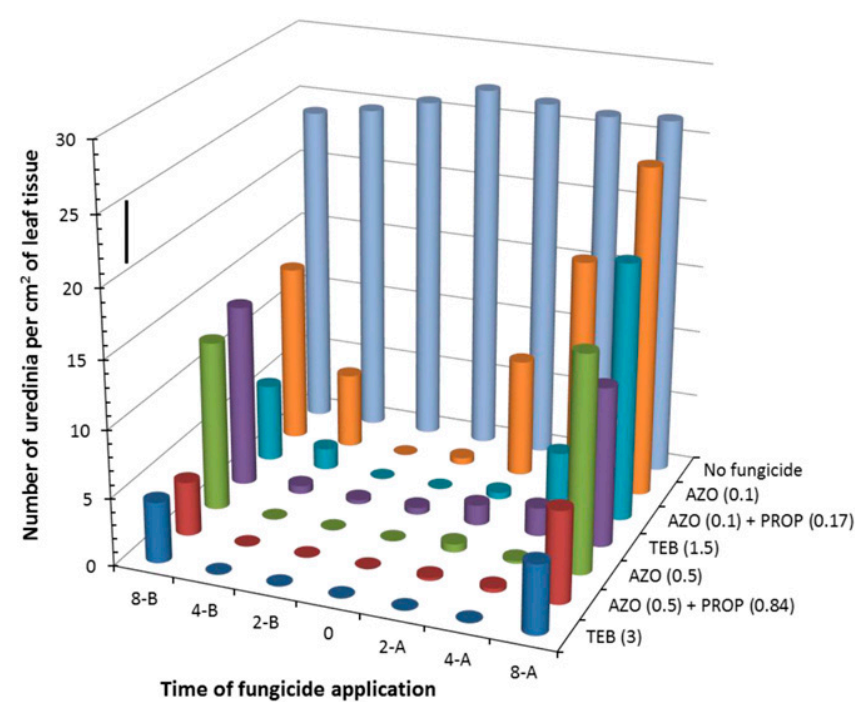

Fig. 2. Number of uredinia on leaves for soybean cultivar Williams 82 after applying or not applying fungicides 8 days before (8-B) to 8 days after (8-A) Phakopsora pachyrhizi inoculation in the greenhouse. Fungicides are azoxystrobin (AZO), tebuconazole (TEB), and propiconazole (PROP) with rates in $\mu \mathrm{g}$ a.i./ml (ppm) after each fungicide. The vertical bar represents LSD value at $\alpha=0.05$ for all treatments. growth at a concentration of $20 \mu \mathrm{g} / \mathrm{ml}$ of aluminum tris (Subba Rao et al. 1992). In contrast to the low $\mathrm{EC}_{50}$ values reported for spore germination, high $\mathrm{EC}_{50}$ values, ranging from 1,256 to $1,508 \mu \mathrm{g} / \mathrm{ml}$ of aluminum tris, were required to inhibit the mycelial growth of Pythium irregulare, $P$. sylvaticum, and P. ultimum by $50 \%$ (Weiland at al. 2014). Also, aluminum tris caused $0 \%$ mycelial growth inhibition when it was tested at $2,000 \mu \mathrm{g} / \mathrm{ml}$ against five fungi (Dothiorella iberica, Neofusicoccum australe, $N$. luteum, N. parvum, and Phomopsis sp.) (Twizeyimana et al. 2013).

The sensitivity of germinating urediniospores of $24 P$. pachyrhizi isolates to azoxystrobin resulted in $\mathrm{EC}_{50}$ values from 0.04 to $0.27 \mu \mathrm{g} / \mathrm{ml}$, which were lower than the range $(0.14$ to $2.47 \mu \mathrm{g} / \mathrm{ml})$ previously reported (Schmitz et al. 2014). The higher $\mathrm{EC}_{50}$ values (Schmitz et al. 2014) may be explained by the use of Brazilian and Taiwanese isolates, which we believe were collected from field samples that may have been intensively sprayed with fungicides. For tebuconazole, the $\mathrm{EC}_{50}$ values recorded in the urediniospore germination assay ranged from 1.54 to $3.71 \mu \mathrm{g} / \mathrm{ml}$. This range, although not as broad as previous reports that used different methodologies, it is within the ranges reported using isolates from Brazil and Taiwan (0.01 to $10 \mu \mathrm{g} / \mathrm{ml}$; Schmitz et al. 2014) and Brazil $(0.016$ to $3.9 \mu \mathrm{g} / \mathrm{ml}$; Godoy 2012). There were significant differences in isolate $\mathrm{EC}_{50}$ values for each fungicide, indicating differences in isolate sensitivity to each fungicide.

Insensitivity of fungi to fungicides occur more frequently in single-site-specific or single mode of action fungicides, especially when a fungicide has been used intensively on a crop; this is characterized by modifications of the biochemical target site in the pathogen, which decreases the affinity of the fungicide for its target (Brent and Hollomon 2007). Few P. pachyrhizi isolates in our study had high $\mathrm{EC}_{50}$ values when treated with azoxystrobin or tebuconazole, indicating strong likelihood that resistance has started to develop in P. pachyrhizi populations in the U.S. to an extent that may be causing failure or significant diminution of disease control by these fungicides. This is supported by reports of triazoles found to be ineffective in controlling SBR after 5 years of applications in Brazil (Godoy 2012). This insensitivity to DMI fungicides was reported to be due to multiple independent point mutations, over-expression of the target gene cyp51, or up-regulation of efflux-transporter (Schmitz et al. 2014), while the insensitivity to QoI fungicides can be caused by the occurrence of the F129 L mutation in the cytochrome $b$ gene of $P$. pachyrhizi (Klosowski et al. 2015). There is a possibility of fungicide resistance developing in $P$. pachyrhizi populations in the southern U.S. as growers often apply fungicide more than once per season, especially when the risk of SBR is relatively high (Sikora 2013; Sikora et al. 2014).

The curative and preventive effects of fungicides and application times are important considerations in developing management strategies for SBR. In our study, all treatments significantly reduced fungal sporulation compared with the nonfungicide control. The exceptions were a few treatments applied at lower rates or at 6 or 8 days after inoculation. In another study that evaluated five fungicides and application timing to control species of Puccinia on daylily, geranium, and sunflower, the fungicides reduced lesion development but their the efficacy decreased as the time from application to inoculation (preventative properties) or inoculation to application (curative properties) increased (Mueller et al. 2004).

We found that the mixture of azoxystrobin $(0.5 \mu \mathrm{g}$ a.i. $/ \mathrm{ml})+$ propiconazole $(0.84 \mu \mathrm{g}$ a.i./ml $)$ had fewer sporulating uredinia per $\mathrm{cm}^{2}$ leaf tissue and more preventative and curative activity than any other fungicide application except application with tebuconazole $(3 \mu \mathrm{g}$ a.i./ml). Triazole and strobilurin fungicides have been intensively used to control SBR. However, it was reported in Brazil that fungicides in both groups were less effective than when used alone, and that combinations of strobilurins and triazoles had better disease control (Godoy 2012; Scherm et al. 2009). Similarly in field trials, the mixture cyproconazole + azoxystrobin had higher preventative and curative activity, while propiconazole applied alone had only curative activity (Mueller et al. 2004).

All fungicide applications in our experiments had some preventive and curative activities, albeit with significant differences. However, 
in general, fungal sporulation was lower when fungicides were applied preventatively. This corroborates what was reported in field experiments, where fungicide applications made prior to the first detection of SBR were associated with lower disease severity and greater yields than those made after the first detection (Mueller et al. 2009). Similarly, fungicides sprayed as preventive treatments for controlling SBR in South Africa generally had higher yields and lower disease severity than those sprayed as curative treatments (Du Preez and Caldwell 2004).

Soybean rust can be effectively managed by the use of diseaseresistant cultivars, appropriate cultural practices, and through the timely application of appropriate fungicides (Levy 2005; Miles et al. 2007; Mueller et al. 2009, Twizeyimana et al. 2008, 2011). However, currently the management of SBR relies primarily on the application of fungicides, and their efficiency depends largely on correct timing of applications. The significant differences found in $\mathrm{EC}_{50}$ values among isolates used in our fungicide sensitivity study reminds us that there is high "risk of resistance" in P. pachyrhizi populations to most fungicides used in SBR management. This supports the recommendation by FRAC to apply these fungicides always in mixtures, and apply them preventively, or as early as possible, in the disease cycle. Information on $P$. pachyrhizi isolate sensitivity to fungicides, their preventive and curative effects, and the timing of application of different fungicides, are all key to factors in the management of soybean rust.

\section{Acknowledgments}

We thank Theresa Herman for her assistance in reviewing the manuscript.

\section{Literature Cited}

Bartlett, D. W., Clough, J. M., Godwin, J. R., Hall, A. A., Hamer, M., and ParrDobrzanski, B. 2002. The strobilurin fungicides. Pest Manag. Sci. 58:649-662.

Blum, M. M. C., and Reis, E. M. 2013. Phakopsora pachyrhizi in vitro sensitivity to fungicides. Summa Phytopathol. 39:215-216.

Brent, J. K., and Hollomon, D. W. 2007. Pages 1-28 in: Fungicide resistance: the assessment of risk. FRAC Monograph No. 2. Fungicide Resistance Action Committee, Brussels, Belgium.

Brent, K. J. 1988. Monitoring for fungicide resistance. Pages 9-11 in: Fungicide Resistance in North America. C. J. Delp, ed. The American Phytopathological Society, St. Paul, MN.

Christiano, R. S. C., and Scherm, H. 2007. Quantitative aspects of the spread of Asian soybean rust in the southeastern United States, 2005 to 2006. Phytopathology 97: 1428-1433.

Debieu, D., Bach, J., Hugon, M., Malosse, C., and Leroux, P. 2001. The hydroxyanilide fenhexamid, a new sterol biosynthesis inhibitor fungicide efficient against the plant pathogenic fungus Botryotinia fuckeliana (Botrytis cinerea). Pest Manag. Sci. 57:1060-1067.

Du Preez, E. D., and Caldwell, P. M. 2004. Chemical control of soybean rust (Phakopsora pachyrhizi) in South Africa. Pages 431-435 in: Proc. VII World Soybean Res. Conf., IV Int. Soybean Processing and Utilization Conf., III Congresso Mundial de Soja (Brazilian Soybean Conf.). F. Moscardi, C. B. Hoffman-Campo, O. Ferreira Saraiva, P. R. Galerani, F. C. Krzyzanowski, and M. C. Carrão-Panizzi, eds. Embrapa Soybean, Londrina, Brazil.

Fehr, W. R., Caviness, C. E., Burmood, D. T., and Pennington, J. S. 1971. Stage of development descriptions for soybeans, Glycine max (L.). Merrill. Crop Sci. 11:929-931.

Godoy, C. V. 2012. Risk and management of fungicide resistance in the Asian soybean rust fungus. Pages 87-95 in: Fungicide resistance in crop protection: Risk and management. T. S. Thind, ed. CABI Publishing, Wallingford, U.K.

Hartman, G. L., Hines, R. A., Faulkner, C. D., Lynch, T. N., and Pataky, N. 2007. Late season occurrence of soybean rust caused by Phakopsora pachyrhizi on soybean in Illinois. Plant Dis. 91:466.

Hartman, G. L., Miles, M. R., and Frederick, R. D. 2005. Breeding for resistance to soybean rust. Plant Dis. 89:664-666.

Hartman, G. L., Sikora, E. F., and Rupe, J. C. 2015. Rust. Pages 56-59 in: Compendium of Soybean Diseases and Pests. G. L. Hartman, E. F. Sikora, and J. C. Rupe, eds. American Phytopathological Society, St. Paul, MN.

Hartman, G. L., Wang, T. C., and Tschanz, A. T. 1991. Soybean rust development and the quantitative relationship between rust severity and soybean yield. Plant Dis. 75:596-600.

Hincapie, M., Wang, N.-Y., Peres, N. A., and Dewdney, M. M. 2014. Baseline sensitivity of Guignardia citricarpa isolates from Florida to azoxystrobin and pyraclostrobin. Plant Dis. 98:780-789.

Isard, S. A., Russo, J. M., Magarey, R. D., Golod, J., and VanKirk, J. R. 2015. Integrated pest information platform for extension and education (iPiPE): Progress through sharing. J. Integr. Pest Manage. 6:15.
Ishii, H. 2006. Impact of fungicide resistance in plant pathogens on crop disease control and agricultural environment. Jpn. Agric. Res. Q. 40:205-211

Jarvie, J. A. 2009. A review of soybean rust from a South African perspective. S. Afr. J. Sci. 105:105-108.

Jo, Y. K., Niver, A. L., Rimelspach, J. W., and Boehm, M. J. 2006. Fungicide sensitivity of Sclerotinia homoeocarpa from golf courses in Ohio. Plant Dis. 90:807-813.

Kelly, H. Y., Dufault, N. S., Walker, D. R., Isard, S. A., Schneider, R. W., Giesler, L. J., Wright, D. L., Marois, J. J., and Hartman, G. L. 2015. From select agent to an established pathogen: The response to Phakopsora pachyrhizi (soybean rust) in North America. Phytopathology 105:905-916.

Klosowski, A. C., May De Mio, L. L., Miessner, S., Rodrigues, R., and Stammler, G. 2015. Detection of the F129L mutation in the cytochrome b gene in Phakopsora pachyrhizi. Pest Manag. Sci. 72:1211-1215.

Koenning, S. R., Frye, J. W., Butler, S. C., and Creswell, T. C. 2007. First report of Phakopsora pachyrhizi on kudzu (Pueraria montana var. lobata) in North Carolina and increased incidence of soybean rust on soybean in 2006. Plant Dis. 91:637.

Leroux, P. 1996. Recent developments in the mode of action of fungicides. Pestic. Sci. 47:191-197.

Levy, C. 2005. Epidemiology and chemical control of soybean rust in southern Africa. Plant Dis. 89:669-674

Li, X., Engelbrecht, C. J., Mueller, D. S., and Yang, X. B. 2008. First report of soybean rust caused by Phakopsora pachyrhizi in Iowa and its statewide occurrence. Plant Dis. 92:975

Miles, M. R., Hartman, G. L., Levy, C., and Morel, W. 2003. Current status of soybean rust control by fungicides. Pestic. Outlook 14:197-200.

Miles, M. R., Levy, C., Morel, W., Mueller, T., Steinlage, T., van Rij, N., Frederick, R. D., and Hartman, G. L. 2007. International fungicide efficacy trials for the management of soybean rust. Plant Dis. 91:1450-1458.

Miller, T. C., and Gubler, W. D. 2004. Sensitivity of California isolates of Uncinula necator to trifloxystrobin and spiroxamine, and update on triadimefon sensitivity. Plant Dis. 88:1205-1212.

Mueller, D. S., Jeffers, S. N., and Buck, J. W. 2004. Effect of timing of fungicide applications on development of rusts on daylily, geranium, and sunflower. Plant Dis. 88:657-661.

Mueller, T. A., Miles, M. R., Morel, W., Marois, J. J., Wright, D. L., Kemerait, R. C., Levy, C., and Hartman, G. L. 2009. Effect of fungicide and timing of application on soybean rust severity and yield. Plant Dis. 93:243-248.

Park, S., Chen, Z.-Y., Chandra, A. K., Schneider, R. W., and Hollier, C. A. 2008 Viability of Phakopsora pachyrhizi urediniospores under simulated southern Louisiana winter temperature conditions. Plant Dis. 92:1456-1462.

Patil, P. V., and Anahosur, K. H. 1998. Control of soybean rust by fungicides. Indian Phytopathol. 51:265-268.

Pontzen, R., and Scheinpflug, H. 1989. Effects of triazole fungicides on sterol biosynthesis during spore germination of Botrytis cinerea, Venturia inaequalis and Puccinia graminis f. sp. tritici. Eur. J. Plant Pathol. 95:151-160.

Russell, P. E. 2005. Sensitivity baselines in fungicide resistance research and management. FRAC Monograph No. 3. Fungicide Resistance Action Committee, Brussels, Belgium.

Scherm, H., Christiano, R. S. C., Esker, P. D., Del Ponte, E. M., and Godoy, C. V. 2009. Quantitative review of fungicide efficacy trials for managing soybean rust in Brazil. Crop Prot. 28:774-782.

Schmitz, H. K., Medeiros, C.-A., Craig, I. R., and Stammlerd, G. 2014. Sensitivity of Phakopsora pachyrhizi towards quinone-outside-inhibitors and demethylation inhibitors, and corresponding resistance mechanisms. Pest Manag. Sci. 70: $378-388$.

Sikora, E. J. 2013. Observations on soybean rust management in Alabama in 2012 Proc. Southern Soybean Dis. Workers. 40th Annu. Meeting.

Sikora, E. J., Allen, T. W., Wise, K. A., Bergstrom, G., Bradley, C. A., Bond, J., Brown-Rytlewski, D., Chilvers, M., Damicone, J., DeWolf, E., Dorrance, A., Dufault, N., Esker, P., Faske, T. R., Giesler, L., Goldberg, N., Golod, J., Gomez, I. R. G., Grau, C., Grybauskas, A., Franc, G., Hammerschmidt, R., Hartman, G. L., Henn, A., Hershman, D., Hollier, C., Isakeit, T., Isard, S., Jacobson, B., Jardine, D., Kemerait, B., Koenning, S., Langham, M., Malvick, D., Markell, S., Marois, J. J., Monfort, S., Mueller, D., Mueller, J., Mulroony, R., Newman, M., Osborne, L., Padgett, G. B., Ruden, B. E., Rupe, J., Schneider, R., Schwartz, H., Shaner, G., Singh, S., Stromberg, E., Sweets, L., Tenuta, A., Vaiciunas, S., Yang, X. B., Young-Kelly, H., and Zidek, J. 2014. A coordinated effort to manage soybean rust in North America: a success story in soybean disease monitoring. Plant Dis. 98:864-875.

Subba Rao, P. V., Geiger, J. P., Savary, S., and Ravise, A. 1992. Reactions of rust-infected groundnut genotypes following treatment with fosetyl-Al, a-aminooxyacetate, and inoculation with Puccinia sorghi Schw. Oleagineux 47:573-578.

Tremblay, D. M., Talbot, B. G., and Carisse, O. 2003. Sensitivity of Botrytis squamosa to different classes of fungicides. Plant Dis. 87:573-578.

Twizeyimana, M., and Hartman, G. L. 2010. Culturing Phakopsora pachyrhizi on detached leaves and urediniospore survival at different temperatures and relative humidities. Plant Dis. 94:1453-1460.

Twizeyimana, M., and Hartman, G. L. 2012. Pathogenic variation of Phakopsora pachyrhizi isolates on soybean in the United States from 2006 to 2009. Plant Dis. 96:75-81. 
Twizeyimana, M., McDonald, V., Mayorquin, J. S., Wang, D. H., Na, F., Akgül, D. S., and Eskalen, A. 2013. Effect of fungicide application on the management of avocado branch canker (formerly Dothiorella canker) in California. Plant Dis. 97:897-902.

Twizeyimana, M., Ojiambo, P. S., Hartman, G. L., and Bandyopadhyay, R. 2011. Dynamics of soybean rust epidemics in sequential plantings of soybean cultivars in Nigeria. Plant Dis. 95:43-50.

Twizeyimana, M., Ojiambo, P. S., Ikotun, T., Ladipo, J. L., Hartman, G. L., and Bandyopadhyay, R. 2008. Evaluation of soybean germplasm for resistance to soybean rust (Phakopsora pachyrhizi) in Nigeria. Plant Dis. 92:947-952.
USDA. 2016. Pest Information Platform for Extension and Education. Available online from: http://www.sbrusa.net

Watson, S. R., Giesler, L. J., Ziems, A. D., and Brovont, T. E. 2008. First report of soybean rust caused by Phakopsora pachyrhizi in Nebraska. Plant Dis. 92:1588.

Weiland, J. E., Santamaria, L., and Grünwald, N. J. 2014. Sensitivity of Pythium irregulare, $P$. sylvaticum, and $P$. ultimum from forest nurseries to mefenoxam and fosetyl-Al, and control of Pythium damping-off. Plant Dis. 98:937-942.

Yorinori, J. T., Paiva, W., Frederick, R. D., Castamilan, L., Bertagnolli, P., Hartman, G. L., Godoy, C., and Nunes, J. J. 2005. Epidemics of soybean rust (Phakopsora pachyrhizi) in Brazil and Paraguay from 2001 to 2003. Plant Dis. 89:675-677. 